\title{
Dacryocystorrhinostomia mútétek során eltávolított könnytömlőminták szövettani elemzése
}

\author{
Sohajda Zoltán dr. ${ }^{1}$ - Hargitai Zoltán dr. ${ }^{2}$ \\ Török Miklós dr. ${ }^{2}$ - Nagy Tibor dr. ${ }^{3}$ \\ Debreceni Egyetem, Kenézy Gyula Egyetemi Kórház, ' Szemészeti Osztály, ${ }^{2}$ Patológiai Osztály, \\ ${ }^{3}$ Fül-Orr-Gégegyógyászati Osztály, Debrecen
}

Bevezetés: Az endonasalis dacryocystorrhinostomia (EDCR) jó eredményességű.

Célkitüzés: Az EDCR során eltávolított könnytömlőfalminták szövettani prospektív elemzése.

Módszer: 2016 és 2017 között 21 EDCR-t végeztünk. 2 betegcsoportot állítottunk fel: gyulladásos tünetekkel (11 beteg) vagy azok nélkül (10 beteg) fennálló könnycsorgás. Az átlagéletkor 60,5 év volt. A szövettani mintákat hematoxilin-eozin festés után vizsgáltuk.

Eredmények: A könnyezéses csoportban a könnytömlő falának több magsoros csillószőrös hengerhámjában kezdődő laphám-metaplasia volt látható. A saccus falában krónikus gyulladás zajlik, a serosus mirigyek mucinosus metaplasiájával. A gyulladásos csoportban a csillószőrös hengerhám laphám-metaplasiája kifejezett. A könnytömlő falát krónikus fibroticus gyulladás destruálja. A serosus mirigyek mucinosus metaplasiája kifejezett, szekrétuma tágulatot okoz, amely rupturálhat.

Következtetések: Szövettani vizsgálataink szerint a gyulladásos és a könnycsorgásos panaszok mellett végzett EDCR során eltávolított könnytömlő hisztológiai jellemzői hasonlóak.

Orv Hetil. 2018; 159(52): 2207-2211.

Kulcsszavak: dacryocystorrhinostomia, szövettani vizsgálat

\section{Histological investigation of the walls of lacrimal sacs removed in the course of dacryocystorhinostomy}

Introduction: Endonasal dacryocystorhinostomy (EDCR) has good results.

Aim: To perform a prospective histological investigation of the removed lacrimal sacs' walls.

Method: Between 2016 and 2017, we carried out 21 operations in two groups: inflammatory ( 11 patients) and noninflammatory (10 patients) lacrimation groups. The mean age was 60.5 years. Histological samples were investigated after staining them with hematoxylin-eosin.

Results: In the non-inflammatory group, histology revealed the incipient metaplasia of the ciliated goblet cells. In the lacrimal sac's wall, there is a chronic inflammation with mucinous metaplasia of the serous glands. In the inflammatory group, the metaplasia of the ciliated goblet cells is more pronounced. Chronic fibrotic inflammation destroys the lacrimal sac's wall, which is dilated, ruptured. The mucinous metaplasia of the serous glands is pronounced.

Conclusions: The results of histological investigations of the lacrimal sacs removed in the course of EDCR are much alike in the inflammatory and non- inflammatory groups.

Keywords: dacryocystorhinostomy, histological investigation

Sohajda Z, Hargitai Z, Török M, Nagy T. [Histological investigation of the walls of lacrimal sacs removed in the course of dacryocystorhinostomy]. Orv Hetil. 2018; 159(52): 2207-2211.

(Beérkezett: 2018. július 5.; elfogadva: 2018. augusztus 5.) 


\section{Rövidítések}

CT = (computed tomography) számítógépes tomográfia; DCR $=($ dacryocystorhinostomy $)$ dacryocystorrhinostomia $; \mathrm{EDCR}=$ (endonasal dacryocystorhinostomy) endonasalis dacryocystorrhinostomia; PANDO $=$ (primary acquired nasolacrimal duct obstruction) ductus nasolacrimalis primer obstrukciója; SALDO $=$ (secondary acquired nasolacrimal duct obstruction $)$ másodlagos könnyútobstrukció

A dacryocystorrhinostomia (DCR) mútét a Toti által történt első közlése óta igen nagy fejlődésen ment keresztül. A behatolás módja szerint alapvetôen a DCReknek 3 ága alakult ki. A külső behatolásból történő mütétek Dupuy-Dutemps és Bourguet által (1904, 1921-ben) leírt technikája terjedt el és használatos manapság is. A DCR-ek másik nagy ága az endonasalis behatolásból végzett mútét. A modern endoszkópos, endonasalis mútétek alapjait McDonogh és Meiring tette le több mint negyedszázada [1]. Alapvetôen mindkét technika során a 12-15 mm hosszú saccus lacrimalist érjük el és nyitjuk meg végső soron, de az endoszkópos technikával alacsonyabb régióban, mint a külső behatolásból végzett $\mathrm{DCR}$ esetén, ami a saccuson belüli manipulációt érdemben nem befolyásolja $[2,3]$. Ezenkívül meg kell még említeni a legújabb DCR-technikát, az endocanalicularis lézerasszisztált DCR-t is $[1,4]$. Ezen mútétek eredményessége igen nagy, amirôl hazai szerzők közleményeiből is tájékozódhatunk. Nagymihály és mtsai arról számolnak be, hogy az externalis DCR után a könnyutak 93\%-ban átjárhatók beteganyagukban, míg Csokonai az endoszkópos DCR-ek gyógyulási arányát 76,5\%-osnak találta; Helfferich a mútét sebészi eredményességét $85 \%$ ra teszi [5-7]. Helfferich és munkacsoportja a transcanalicularis lézeres DCR-t 67,5\%-ban ítélte sikeresnek, de a betegek szubjektív megítélése alapján $84 \%$-ban volt sikeres a beavatkozás [4]. A mútét indikációs köre hasonló: a saccus és ductus nasolacrimalis obstrukciója, valamint funkcionális szúlkülete, amikor átfecskendezhető könnyutak mellett a beteg könnycsorgásról panaszkodik. A panaszok hátterében két fó mechanizmus állhat. Időskorban a leggyakrabban a ductus nasolacrimalis primer obstrukciója (PANDO) okoz könnycsorgást. Ebben az esetben a ductus nasolacrimalis mucosájának krónikus gyulladása progresszív fibrosist és a ductus szúkületét okozza [8]. Patomechanizmus szerint a másik fó csoport a másodlagos könnyútobstrukció (SALDO), amely a könnylevezető rendszer bármely szakaszának gyulladása, neoplasiája, traumája, mechanikus elzáródása következtében alakul ki [9].

A canaliculus communistól distalisan jelentkező szükület, illetve obstrukció esetén a DCR hatásosan alkalmazható [1, 4-7]. Miután operáció közben lehetőség nyílik a könnytömlő egy részének eltávolítására, ennek szövettani feldolgozását végeztük el. Munkánk motivációját az adta, hogy annak ellenére, hogy csaknem százéves mútéti technikáról van szó, viszonylag kevés az ennek kapcsán végzett hisztológiai elemzés. A gyulladásos ala- pon kialakuló elzáródás és a funkcionális szúküulet miatt elvégzett DCR-ek során eltávolított könnytömlőminták hisztológiai elemzését és összevetését végeztük el, összefüggéseket keresve a szövettani és a klinikai kép közöttt.

\section{Módszer}

2016. január és 2017. december között elvégzett DCRek során eltávolított könnytömlőminták szövettani elemzését végeztük el prospektíven. A betegek esetében általános szemészeti vizsgálatot követően átfecskendezéssel győződtünk meg a könnyutak átjárhatóságáról. Szükség esetén dacryocystographiát, illetve egyéb képalkotó vizsgálatot (CT, szcintigráfia) is végeztünk. DCR-t csak abban az esetben indikáltunk, ha a patológiás folyamatot a saccus, illetve a ductus nasolacrimalis szintjében észleltük. Akut gyulladásos tünetek esetén nem végeztünk mútétet, ilyenkor a beavatkozás a panaszok konzervatív kezelése után, azok elmúltával történt meg. Betegeinknél nem végeztünk rutinszerúen tenyésztéses vizsgálatot a könnytömlő tartalmából. A vizsgált időszakban 21 beteg egyoldali mútétjét végeztük el. A betegek átlagéletkora 60,5 év, férfi/nő megoszlása $7 / 14$ volt. A mútét hátterében 11 betegnél könnytömlő-váladékozással együtt járó krónikus gyulladás, 10 betegnél gyulladás nélküli funkcionális zavar állt.

A mútéteket a Fül-Orr-Gégészeti Osztályon, a fül-orrgégész aktív közremúköódésevel narkózisban végeztük a következő́k szerint. Az orrnyálkahártyát $5 \%$-os kokainoldat segítségével lohasztjuk le. Merev csöves 30 fokos endoszkóp ellenőrzése mellett a középső orrkagyló tapadása mellett az orrnyálkahártyát a csontról leválasztjuk. A lateralis csontos orrfalon gyémántfejü fúróval lyukat készítünk, amíg a könnytömlő medialis fala szabaddá nem válik. A könnytömlő felkeresésében az alsó könnyponton és canaliculuson át bejuttatott 23 G-s száloptika volt segítségünkre. Itt a könnytömlő falának egy darabját fogóval eltávolítottuk. Majd a mútét végén a könnypontokon és canaliculusokon át a duplán fegyverzett O'Donoghueféle szilikonfonalat (Beaver-Visitec, Waltham, MA, Amerikai Egyesült Államok) juttattuk be, amelynek szárait a könnytömlő imént elkészített nyílásán keresztül behúztuk az orrüregbe, majd megcsomóztuk.

$\mathrm{Az}$ eltávolított könnytömlődarab 8\%-os formalinba került. A fixált szövettani anyagokat paraffinba ágyazták a hisztológusok. Ezt követte a minták hematoxilin-eozin festése a következő́k szerint: a metszetekből első lépésben a paraffin kioldása történt xilollal, majd a metszetek leszálló alkoholsor alkalmazása után hematoxilinba kerülnek 1-2 percre. Ezt követi a vizes közegben végzett kékítés, majd eozinos festés. Ezután felszálló alkoholsorral víztelenítés és a metszetek fedése történik.

\section{Eredmények}

A könnyezéses panaszok miatt mútétre került betegek könnytömlőinek falát jellemzően több magsoros csilló- 


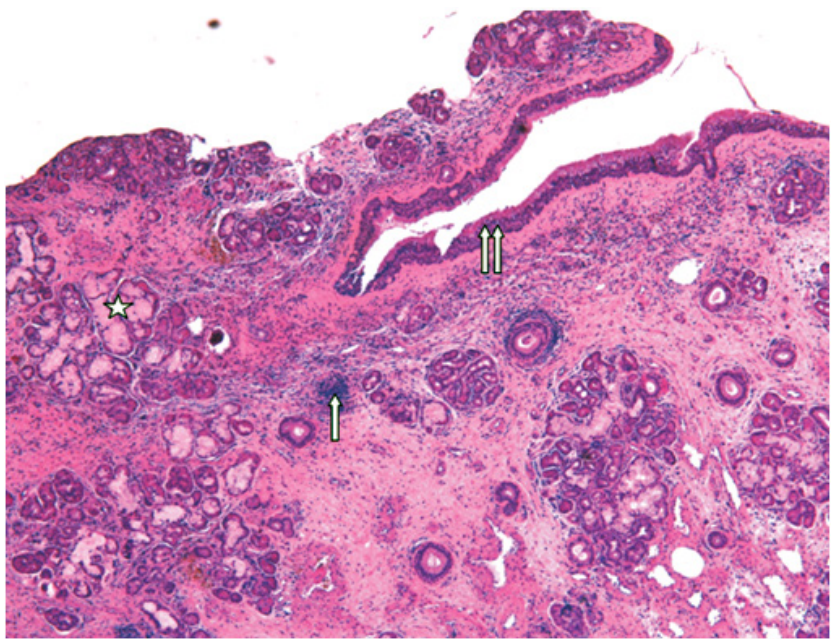

1. ábra

Hyperplasticus serosus mirigyvégkamrák mucinosus metaplasiával, egy-egy mirigy szekrétum okozta tágulatával, periductalisan krónikus-lobos beszürődéssel (fehér csillag). A fibroticus stromában lymphocytás beszúrődés (fehér nyíl) és hyperplasticus falú erek láthatók. A könnytömlő falát ép, több magsoros csillószőrös hengerhám (dupla fehér nyíl) borítja, kezdődő laphám metaplasiával. Hematoxilin-eozin festés, $100 \times$-os nagyítás

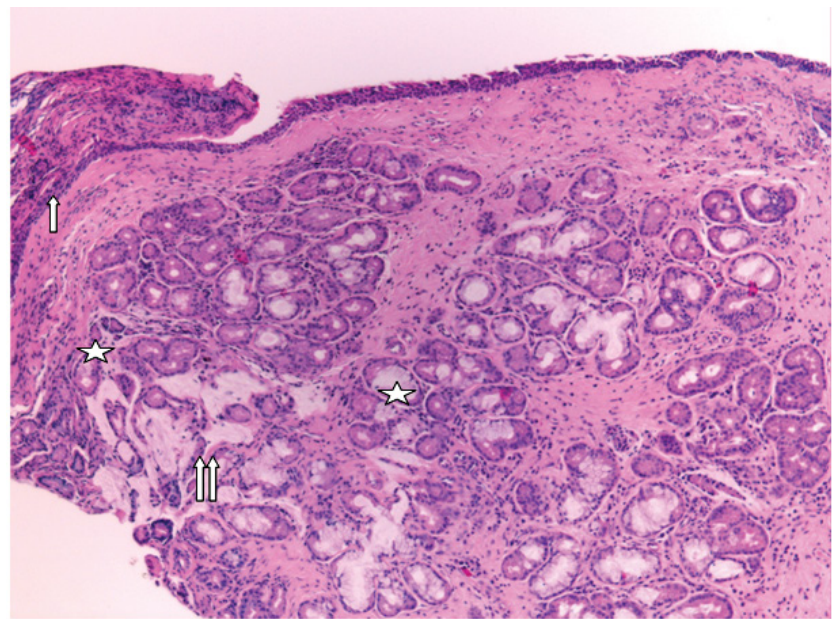

2. ábra

Részben csillószőrös hengerhámmal, részben éretlen, illetve érett laphám-metaplasiás hámmal (fehér nyíl) borított fibroticus könnytömlőfal részlete. Fibroticus, mucinosus metaplasiát mutató hyperplasticus mirigyvégkamrák láthatók (fehér csillag). A mirigyszekrétum mirigytágulatot és rupturát okozott, az alapállomány szekrétummal beivódott (dupla fehér nyíl). Hematoxilin-eozin festés, 100×-os nagyítás

szőrös hengerhám borítja, kezdődő laphám-metaplasiával. A könnytömlő falában krónikus gyulladás zajlik, amely az itt lévő serosus mirigyekre is ráterjed. Ezen mirigyek mucinosus metaplasiát mutatnak, és jelentősen kitágultak (1. és 2. ábra).

A gyulladásos panaszok miatt mútétre került betegekből eltávolított könnytömlő szövettani elemzése során megállapítható, hogy a csillószőrös hengerhám laphámmetaplasiája kifejezett. A könnytömlő falát krónikus fibroticus gyulladás destruálja. A serosus mirigyek metaplasiája kifejezett. A mirigyek szekrétuma tágulatot okoz, amely rupturát válthat ki (3. ábra).

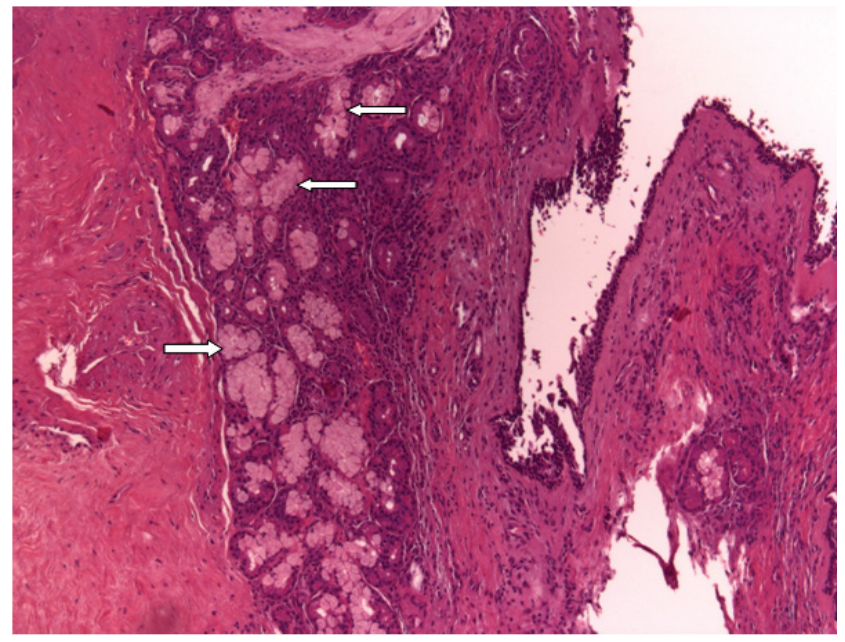

3. ábra

Könnytömlőfal részlete, ahol a krónikus fibroticus gyulladást mutató mirigyekben hyperplasticus serosus mirigyvégkamrák láthatók mucinosus metaplasiával (fehér nyíl). Hematoxilin-eozin festés, 100×-os nagyítás

A gyulladásos és a könnycsorgásos panaszok mellett nem átjárható alsó könnyutak esetén végzett endonasalis DCR-ek során eltávolított könnytömlő hisztológiai jellemzői hasonlóak.

\section{Következtetések}

A DCR-ek indikációja a könnyutak saccalis/postsaccalis szúkülete, illetve elzáródása. Alapvetôen 2 fó tünetcsoport köré lehet a beavatkozást kiváltó kórképeket csoportosítani: epiphora és váladékozással járó gyulladás. Ezen mútétek kivitelezésére két mútéti technika terjedt el a leginkább: a külső és belső behatolásból végzett DCR. Ezek eredményességéről hazai közlemények is rendelkezésünkre állnak az utóbbi évekből [5-7]. Ezek, valamint más adatok szerint a külső DCR eredményessége 90-95\%, míg az endonasalis behatolásból végzetté $76-85 \%[5-7,10]$. Korábbi saját beteganyagunkon végzett vizsgálataink szerint -40 betegen (traumás, könnycsorgásos, gyulladásos betegcsoport) végzett 50 endonasalis endoszkópos DCR - a sikerességi arány 76-77\%-os volt. Sikeresnek akkor tekintettük a mútétet, ha a könnyutak átfecskendezhetővé váltak, és a beteg panaszai megszüntek [11].

A DCR során eltávolított könnytömlő falának szövettani elemzéséről sokkal kevesebb adat áll rendelkezésre, mint a mútét eredményességéről. Lee és mtsai az endonasalis DCR-ek utáni restenosisos eseteket vizsgálták hisztológiai szempontból. Két csoportot különítettek el attól függően, hogy használtak-e a mútét során stentet. Mindkét csoportra jellemző volt a krónikus könnytömlőfalgyulladás, kísérő fibrosissal. A több magsoros hengerhám sejtdenzitása csökkent volt vizsgálataik szerint, a stent jelenlététől függetlenül. Megállapítják, hogy a könnytömlő fibrosisának intenzitásnövekedése állhat a 
restenosisok hátterében, ami a szövettani vizsgálatok jelentőségét húzza alá [12].

Szintén a hisztológiai vizsgálatok jelentőségét emeli ki Ali és mtsai munkája, akik a mütét eredménytelenségének hátterében a mütét során kialakított új nyílás különböző mértékű granulációját okolják mind endoszkópos, mind külső DCR-ek esetében. Ezen granuláció kialakulása gyulladásos előzményeket követően kifejezettebb [13].

Ozer és mtsai vizsgálták az endoszkópos DCR során eltávolított könnytömlőn észlelt szövettani elemzés prognosztikai szerepét a mütét eredményességével kapcsolatban. Azt találták, hogy az eredménytelen, illetve elégtelen posztoperatív statussal bíró beteg esetében a könnytömlő falának lymphoid sejtes infiltrációja, fibrosisa, capillaris proliferáció jelentősen magasabb arányban fordult elő, mint a sikeres és eredményes mütétek során eltávolított könnytömlőmintákban. A szövettani vizsgálatok során általuk kialakított krónikus gyulladásos jelek rangsorolásával következtetni lehet a szerzők szerint az endoszkópos DCR-ek eredményességére [10].

$\mathrm{Az}$ általunk végzett endonasalis, endoszkópos DCRek során eltávolított könnytömlőminták szövettani elemzése során nem találtunk a török munkacsoportéhoz hasonló összefüggéseket. Ennek hátterében véleményünk szerint az állhat, hogy a krónikus gyulladásos jelek szerinti besorolás szubjektív elemeket tartalmazhat. Másik ok a betegszámokban lévő különbség lehet.

Mind a külső, mind az endoszkópos behatolásból elvégzett DCR-ek egy részénél nem érünk el megfelelő eredményt. Bár két különböző mütéti technikáról van szó, Rootman kadávereken végzett vizsgálatai során kimutatta, hogy az elkészített csontablak nagysága hasonló [2]. Az eredménytelenség különösen nehezen magyarázható azokban a könnyezéses panaszokat okozó esetekben, amelyekben endonasalis DCR után (amikor a medialis canthus képletei megkíméltek, és az aktív könnypumpafunkció intakt marad) a könnyutak átfecskendezhetők, mégis fennállnak a panaszok $[1,6]$. Ennek kapcsán megvizsgálták a könnyutak mucociliaris clearance-ét externalis és endonasalis DCR-ek után, de nem találtak jelentős különbséget [14]. Ilyenkor merül fel a jelentősége a könnytömlő falát borító csillőszőrös hengerhám épségének [14-17]. Ugyanerre hívja fel a figyelmet Mito és munkacsoportja: ők kadáverkönnytömlők szövettani vizsgálatai során azt állapították meg, hogy súlyosan károsodott volt a csillószőrös hengerhám azon saccusok falának belső felszínén, amelyeknél gyulladásos jeleket is találtak [18].

A gyulladásos elváltozások hátterében felmerült a bakteriális kórokozók jelenléte oki tényezőként. Lee és munkacsoportja vizsgálatukban a könnytömlőben a leggyakrabban Pseudomonas-, míg Szathmáry és mtsai Staphylococcus-speciest találtak. Bár ezen kórokozók fontos szemészeti etiológiai szereppel bírnak fóleg keratitisek esetében, mindketten azt állapítják meg, hogy ezen fertőzések másodlagosak, és nem kóroki tényezőként szerepelnek a könnyutak múködészavaraiban [12, 19].

Saját beteganyagunkban a szövettani vizsgálatok során mind a gyulladásos, mind a könnyezéses csoportban azt tapasztaltuk, hogy változó mértékben károsodott volt a tömlő hámja, laphám-metaplasia különböző mértékű jeleit mutatva. Ennek fokozatában nem találtunk különbséget a gyulladás/könnyezés relációjában. Véleményünk szerint a vizsgálataink ilyen irányú későbbi kiterjesztése ígéretes lehet.

Szövettani vizsgálataink kapcsán arra következtethetünk, hogy a gyulladásos és a könnycsorgásos panaszok mellett nem átjárható alsó könnyutak esetén végzett endonasalis DCR-ek során eltávolított könnytömlő hisztológiai jellemzői hasonlóak. Ezek a következők: a tömlő falában krónikus lymphoid infiltráció figyelhető meg, a serosus mirigyek mucinosus metaplasiája látható, a tömlő falának fibroticus átépülése és a csillószőrös hengerhám laphám-metaplasiája mutatható ki. Ezen hisztológiai vizsgálatok a különböző kórképek és tünetek hátterében zajló folyamatok pontosabb megismerését teszik lehetővé.

Anyagi támogatás: A szerzők anyagi támogatásban nem részesültek.

Szerzôi munkamegosztás: S. Z.: A hipotézisek kidolgozása, a vizsgálat lefolytatása, a kézirat elkészítése, megszövegezése. T. M., H. Z.: A hisztológiai vizsgálatok kivitelezése. N. T.: A vizsgálat lefolytatása, a kézirat korrektúrája. A cikk végleges változatát valamennyi szerző elolvasta és jóváhagyta.

Érdekeltségek: A szerzőknek nincsenek érdekeltségeik.

\section{Irodalom}

[1] Olver J. Dacryocystorhinostomy. In: Olver J. (ed.) Colour atlas of lacrimal surgery. 1st edn. Butterworth Heinemann, Oxford, 2002; 94-130: 195 .

[2] Rootman D, De Angelis D, Tucker N, et al. Cadaveric anatomical comparison of the lateral nasal wall after external and endonasal dacryocystorhinostomy. Ophthal Plast Reconstr Surg. 2012; 28: 149-153.

[3] Végh M. Use of Healon as a space stabilizer and bleeding inhibitor material in dacryocystorhinostomy. Orbit 1989; 8: 133-137.

[4] Helfferich F, Reményi Á, Szathmáry E. Comparison of our transcanalicular LASER dacryocysto rhinostomy experience with traditional technique. [A transcanalicularis LASER dacryocystorhinostomiával szerzett tapasztalataink összehasonlítása a hagyományos endoszkópos technikával.] Fül-Orr-Gégegyógyászat 2018; 64: 11-16. [Hungarian]

[5] Helfferich F, Szathmáry E, Vogt G. Technical suggestions to perform endoscopic dacryocystorhinostomy after 40 cases. [Technikai javaslatok az endoscopos dacryocystorhinostomia kivitelezéséhez, 40 eset alapján.] Fül-Orr-Gégegyógyászat 2009; 55: 170-176. [Hungarian]

[6] Csokonai VL, Fodor M, Liktor B. Endonasal, endoscopic dac ryocystorhinostomy with laser. [Endonasalis, endoscopos dacry- 
ocystorhinostomia lézerrel.] Szemészet 1999; 136: 207-209. [Hungarian]

[7] Nagymihály A, Kaan EO, Gábriel I. Our results with dacryocystorhinostomy in our clinic. [A dacryocystorhinostomia-mútétek eredményei klinikánkon.] Szemészet 2008; 145: 59-61. [Hungarian]

[8] Linberg J, McCormick S. Primary acquired nasolacrimal duct obstruction: a clinicopathologic report and biopsy technique. Ophthalmology 1986; 93: 1055-1062.

[9] Bartley GB. Acquired lacrimal drainage obstruction: an aetiologic classification system, case reports and a review of the literature. Ophthalmic Plastic Reconstr Surg. 1992; 8: 237-249.

[10] Ozer O, Eskiizmir G, Unlü H, et al. Chronic inflammation: a poor prognostic factor for endoscopic dacryocystorhinostomy. Eur Arch Otolaryngol. 2012; 269: 839-845.

[11] Sohajda Z, Kiss M, Nagy T, et al. Latest development in the therapy and diagnostics of lacrimal drainage system disorders. [Aktualitások a könnyelvezető rendszer betegségeinek diagnosztikájában és terápiájában.] Szemészet 2012; 142: 36. Suppl. [Hungarian]

[12] Lee JH, Kang MS, Yang JW. Clinicopathologic findings after nasolacrimal polyurethane stent implantation. Korean J Ophthalmol. 2005; 19: 252-257.

[13] Ali MJ, Wormald PJ, Psaltis AJ. The dacryocystorhinostomy ostium granulomas: classification, indications for treatment, management modalities and outcomes. Orbit 2015; 34: 146-151.
[14] Olver J. Anatomy of the lacrimal system. In: Olver J. (ed.) Colour atlas of lacrimal surgery. 1st edn. Butterworth Heinemann, Oxford, 2002; 2-18: 35-37.

[15] Okuyucu S, Akoglu E, Oksuz H, et al. The effect of dacryocystorhinostomy on mucociliary function. Otolaryngol Head Neck Surg. 2009 ; 140: 585-588.

[16] Radnót M, Bölcs S. Die Feinstruktur der Epithelzellenoberfläche des Tränensackes. Klin Mbl Augenheilk. 1971; 159: 158-164.

[17] Radnót M, Gábriel I. New data about the goblet cells of lacrimal sac. [A könnytömlő hámjának kehelysejtjeiról.] Szemészet 1980; 117: 65-67. [Hungarian]

[18] Mito H, Takhashi Y, Nakano T, et al. Consecutive microscopic anatomical characteristics of the lacrimal sac and nasolacrimal duct: cases with or without inflammation. Invest Ophthalmol Vis Sci. 2014; 55: 5233-5237.

[19] Szathmáry E, Helfferich F, Vogt G. Bacteriological examinations results in cases of chronic dacryocystitis. [Mikrobiológiai vizsgálatok eredményei krónikus könnytömlő gyulladás eseteiben.] Szemészet 2014; 151: 90. Suppl. [Hungarian]

(Sohajda Zoltán dr., Debrecen, Bartók B. u. 2-26., 4031 e-mail: zoltansohajda@hotmail.com)

"Muliebris lacrima condimentum est malitiae."

(Az asszonyi könny a rosszindulat füszere.)

\section{A rendezvények és kongresszusok híranyagának leadása}

a lap megjelenése előtt legalább 40 nappal lehetséges, a 6 hetes nyomdai átfutás miatt. Kérjük megrendelőink szíves megértését.

A híranyagokat a következő címre kérjük:

Orvosi Hetilap titkársága: edit.budai@akademiai.hu

Akadémiai Kiadó Zrt. 